\title{
STUDY OF OBSTETRIC AND FETAL OUTCOME OF PREGNANCY IN PREVIOUS CAESAREAN SECTION
}

Gurpreet Kaur Nandmer ${ }^{1}$, Anjali Kanhere ${ }^{2}$

\section{HOW TO CITE THIS ARTICLE:}

Gurpreet Kaur Nandmer, Anjali Kanhere. "Study of Obstetric and Fetal Outcome of Pregnancy in Previous Caesarean Section". Journal of Evolution of Medical and Dental Sciences 2015; Vol. 4, Issue 74, September 14; Page: $12908-12915$, DOI: $10.14260 /$ jemds/2015/1862

ABSTRACT: Previous caesarean section sparks an area of controversy in Obstetrics. The management of women with previous caesarean section regarding the mode of delivery whether to opt for repeat caesarean section or vaginal delivery, is an area of debate. Very often the decision on management is not made on Principle of sound reasoning and many who choose the elective repeat caesarean section do so to circumvent the anxious moment that arise during conduction of labour. AIMS AND OBJECTIVE: To determine the maternal and fetal outcome in relation to type of delivery. MATERIALS AND METHODS: A 18 month prospective observational study was conducted where in 150 patients who had a term pregnancy with a history of prior LSCS were included after obtaining their consent for participation. The obstetric and fetal outcomes of these patients in the present pregnancy were analyzed by Z test. RESULTS: Out of the 150 subjects 78(52\%) were in age group of 26-30 years, $106(70.67 \%)$ patients belonged to the urban population, $116(77.33 \%)$ were booked patients, $107(71.33 \%)$ were housewives, $122(81.33 \%)$ belonged to middle class and $22(14.67 \%)$ were from high socio economic status. 67(44.67\%) were second gravid, $112(74.67 \%)$ were para 1 . Out of total 134 patients $29(21.64 \%)$ had elective caesarean section and $5(3.73 \%)$ patients came as emergency admission and underwent caesarean section. Out of 134 patients, with one previous caesarean section. 32 had spontaneous onset of labour. Out of which 20(68.97\%) had vaginal delivery and $9(31.03 \%)$ had repeat caesarean section. 13 patients had augmentation, $11(84.62 \%)$ had vaginal delivery and $2(15.38 \%)$ had caesarean section. In 58 patients labour was induced $29(50 \%)$ had section. 14 patients out of 50 who had previous 2 caesarean section only 1(7.69\%) patient had spontaneous onset of labour and had caesarean section. 3(92.86\%) patients had elective caesarean section. There were only 2 patients with previous 3 caesarean section. Delivered with elective repeat caesarean section. In 134 patients who had previous one caesarean section in 74(52.2\%) cases had repeat caesarean section and indications for the repeat caesarean sections were scar tenderness (ST) in 17(12.69\%), thin scar (TS) in $27(20.15 \%)$, non-progress of labour (NPOL) in 7(5.22\%), fetal distress (FD) in $18(13.43 \%)$ scar dehiscence (SD) in 2(1.49\%) and others (in 2 cases IUGR and in I case severe PIH) $3(2.24 \%)$. Patients who had baby birth weight less than $2.5 \mathrm{~kg}$ and more than $3.5 \mathrm{~kg}$ had more chances of caesarean section. There was significant relation between baby birth weight and mode of delivery. CONCLUSION: With increase in the maternal age and with increase in baby birth weight, there were more chances of repeat cesarean section.

KEYWORDS: Previous LSCS, VBAC, Maternal outcome, Foetal outcome.

INTRODUCTION: Previous caesarean section sparks an area of controversy in obstetrics. The management of women with previous caesarean section regarding the mode of delivery whether to opt for repeat Caesarean Section or vaginal delivery, is an area of debate.

The ever widening indications for caesarean section in recent times will therefore mean that the decision, pertaining to such a situation will have to be made more frequently than a decade ago. 


\section{ORIGINAL ARTICLE}

Very often the decision on management in not made on principle of sound reasoning and many who choose the elective repeat caesarean section do so to circumvent the anxious moment that arise during conduct of labour.

The dictum "Once a caesarean always a caesarean" was made by Edwin Cragin in 1916. However the question remains unanswered as to which route of delivery should be taken by women with previous caesarean section. In 1980 the National Health Institute of child health and Human Development conference concluded that $25 \%$ to $30 \%$ increase in caesarean rate attributed to repeat caesarean section

VBAC (Vaginal Birth after caesarean section) is considered safe and is often successful in carefully selected population of women with previous caesarean section. Less morbidity is encountered in women with successful vaginal birth after caesarean section (VBACs) versus those with elective repeat caesarean section. ${ }^{1}$ Patients with successful trials of labour experience fewer blood transfusions, fewer postpartum injections, shorter hospital stay and no increased perinatal mortality. Because repeat caesarean deliveries are performed largely to benefit the neonate. ${ }^{2}$ clinicians may often overlook maternal complications resulting in significant morbidity and mortality as a result of the repeat surgeries. ${ }^{3}$ the choice of VBAC over planned repeat caesarean section, like virtually every other medical choice, involves the balancing of risks \& benefits. One point is clear though, "once a caesarean, always a hospital delivery".4

MATERIALS AND METHODS: The present study was conducted on women with previous Caesarean section admitted in the department of Obstetrics and Gynecology in Labour room, Dayanand Medical College and Hospital, Ludhiana. A 18 month prospective observational study was conducted where in 150 patients who had a term pregnancy with a history of prior LSCS were included after obtaining their consent for participation, Mode of delivery along with maternal and fetal outcome was analyzed.

Inclusion Criteria: Women selected for vaginal delivery, had to fulfill following Criteria: Pelvis should be adequate Non recurrent indications for previous caesarean section e.g. Non progress of labour, fetal distress, malpresentations, pregnancy induced hypertension, premature rupture of membranes etc.

Exclusion Criteria: Women who were not taken for vaginal delivery

- Recurrent indication present like CPD and contracted pelvis.

- Foetal distress and meconium stained liquor in present pregnancy.

- Malpresentations - Breech/Transverse lie/Compound presentation.

- Medical disorders like: heart disease, diabetes, tuberculosis.

All pregnant women with previous caesarean section admitted in the department of Obstetrics and Gynecology, in Labour room for delivery were included in the study. They were divided into following groups:

Group A: Women who had vaginal delivery.

Group B: Women undergoing caesarean section with failed trial of labour.

Group C: Women with elective caesarean section.

Group D: Women with previous caesarean section underwent emergency caesarean section.

A detailed general and obstetric history was taken. Complete general physical, Obstetric examination was done. Pelvic assessment was done before subjecting the patient to trial of labour. 


\section{ORIGINAL ARTICLE}

Routine investigations like Hemoglobin, bleeding time, clotting time, AboRh grouping and Urine routine was done. Ultrasonography was done on patients as and when required. Record of intrapartum assessment like duration of labour, mode of delivery, any complication during delivery and outcome was maintained. Maternal and fetal outcome was studied in the subjects. Statistical evaluation was done Z-test i.e. test of proportions.

RESULTS: Out of the 150 subjects $20(13.3 \%)$ were in age group of $21-25$ years, $78(52 \%)$ were in age group of 26-30 years, $48(32 \%)$ were in age group of 31-35 years, and remaining $4(2.67 \%)$ were in age group of 36-40 years. Mean age was 29.2 years. (Table 1), 106(70.67\%) patients belonged to the urban population and $44(29.33 \%)$ belonged to the rural population. $116(77.33 \%)$ were booked patients $34(22.67 \%)$ were unbooked patients. $107(71.33 \%)$ were housewives and $43(28.67 \%)$ were working. $6(4 \%)$ were belonging to low class, $122(81.33 \%)$ belonged to middle class and $22(14.67 \%)$ were from high socio economic status. Out of 150 patients, 67(44.67\%) were second gravida, $112(74.67 \%)$ were para 1. (Table $2 \& 3$ ).

In 134 cases with previous one caesarean section 29 had spontaneous onset of labour, Out of which $20(68.97 \%)$ had vaginal delivery and $9(31.03 \%)$ had repeat caesarean section in 13 patients labour was spontaneous but augmented, 11(84.62\%) had vaginal delivery and 2(15.38\%) had caesarean section.58 patients induction was done, of these $29(50 \%)$ had section. 29 patients elective caesarean was done and in 5 patients they came with emergency condition and underwent caesarean section. In 14 cases with previous 2 caesarean section, I case labour was spontaneous in onset and in rest 13 cases elective caesarean section was performed. In 2 cases with previous 3 caesarean section, elective caesarean section was done.

In 134 patients who had previous one caesarean section in 74(52.2\%) cases had repeat caesarean section and indications for the repeat caesarean sections were scar tenderness (ST) in $17(12.69 \%)$, thin scar (TS) in 27(20.15\%), non-progress of labour (NPOL) in 7(5.22\%), fetal distress (FD) in $18(13.43 \%)$ scar dehiscence (SD) in 2(1.49\%) and others (in 2 cases IUGR and in I case severe PIH) 3(2.24\%).

In 14 patients who had previous two caesarean section, repeat caesarean section was done in 14 cases and indications for the repeat caesarean section Scar tendemess (ST) in I (7.14\%) patient and in $12(85.71 \%)$ patients thin scar (TS) and $1(7.14 \%)$ patient had oligohydramnios. In 2 patients who had previous three caesarean section repeat caesarean section was done for thin scar (TS) 2(100\%). 78 patients were between $26-30$ years, $47(60.26 \%)$ had repeat caesarean section and $31(39.74 \%)$ had successful vaginal delivery. 48 patients in age group of 31-35 years $32(66.67 \%)$ had repeat caesarean section. 4 patients between $36-40$ years, $3(75 \%)$ had repeat caesarean section. Patients had baby birth weight less than $2.5 \mathrm{~kg}$ and more than $3.5 \mathrm{~kg}$ had more chances of caesarean section. There was significant relation between maternal age, baby birth weight and mode of delivery.

DISCUSSION: The age of the patients in our study ranged from 2l-40 years and maximum number of women were in age group of 26-30 years (52y"). Mean age in our study was 29.2 \pm 3.44 years. SAKALA EP. ${ }^{5}$ et al (1990) studied 237 women with mean age of $29.0 \pm 4$ years and TROYER LR. ${ }^{6}$ et al (1992) studied 567 women with mean age of $29 \pm 6$ years.

In our study, out of total 150 patients, trial of labour was given in 101 patients and successful vaginal delivery occurred in 60 (49.5\%) cases. Vardhan et al, ${ }^{7}$ Tan et al, ${ }^{8}$ Shah et al, ${ }^{9}$ and Dhall et al. ${ }^{10}$ 


\section{ORIGINAL ARTICLE}

reported 70 to $80 \%$ success in attempts at VBAC. Chhabra et al. ${ }^{11} \&$ Bhat et al. ${ }^{12}$ gave a $71.2 \% \& 64.6 \%$ success report respectively. 55\% success rate on attempts of VBAC was reported by Suman Poddar. ${ }^{13}$

In 69 cases where previous indication was fetal distress' caesarean section was done in $34(49.28 \%)$ cases and vaginal delivery occurred in 35(50.72\%) cases. However, in 53 cases where the previous indication for caesarean section was Non progress of labour caesarean section was done in $43(81.13 \%)$ cases and successful vaginal delivery occurred in $10(18.87 \%)$ cases only.

In our study there was increase in incidence of caesarean section with increase in maternal age. The incidence of caesarean section was $45 \%$ in age group of 21 to 25 years, whereas the incidence is $75 \%$ in age group of 36 to 40 years. The vaginal delivery rate was 55\% in age group of $21-25$ years and $25 \%$ in age group of 35-40 years. So with increase in maternal age, there was decrease in vaginal delivery rate also reported by Suman Poddar. ${ }^{13}$ In the present study, caesarean section rate was high in patients with baby birth weight less than $2.5 \mathrm{~kg}$ and more than $3.5 \mathrm{~kg}$ ZELOP EM et al (2001). ${ }^{14}$ studied 2749 patients and found that caesarean section rate was $29 \%$ in babies with birth weight less than $4 \mathrm{~kg}$ versus $40 \%$ with birth weight more than $4 \mathrm{~kg}$ and is statistical comparable to our study.

CONCLUSION: Trial of labour after one cesarean section should be encouraged. It was observed in this study that with increase in the maternal age and with increase in baby birth weight, there were more chances of repeat cesarean section. With good antenatal care, proper counselling, strict selection of cases, mandatory institutional confinement and close supervision during labor will help in reducing rate of caesarean section.

FINANCIAL OR CONFLICT OF INTREST: None.

\begin{tabular}{|c|c|c|}
\hline Age (in years) & Number $(\mathbf{n = 1 5 0})$ & Percentage \\
\hline $21-25$ & 20 & $13.93 \%$ \\
\hline $26-30$ & 78 & $52.00 \%$ \\
\hline $31-35$ & 48 & $32.00 \%$ \\
\hline $36-40$ & 4 & $2.67 \%$ \\
\hline
\end{tabular}

Table 1: Distribution of Subjects According to Age

\begin{tabular}{|c|c|c|}
\hline Gravity & Number (n=150) & Percentage \\
\hline 2 & 67 & $44.67 \%$ \\
\hline 3 & 43 & $28.67 \%$ \\
\hline 4 & 29 & $19.33 \%$ \\
\hline 5 & 6 & $4.00 \%$ \\
\hline$>6$ & 5 & $3.33 \%$ \\
\hline
\end{tabular}

Table 2: Distribution of Subjects According to Obstetric History

\begin{tabular}{|c|c|c|}
\hline Parity & Number (n=150) & Percentage \\
\hline 1 & 112 & $74.67 \%$ \\
\hline 2 & 30 & $20.00 \%$ \\
\hline 3 & 6 & $4.00 \%$ \\
\hline 4 & 2 & $1.33 \%$ \\
\hline
\end{tabular}

Table 3: Distribution of Subjects According to Parity 


\section{ORIGINAL ARTICLE}

\begin{tabular}{|c|c|c|c|c|}
\hline \multirow{2}{*}{ Type of Labour } & \multicolumn{2}{|c|}{ Number of Previous Caesarean Section } & \multirow{2}{*}{ Total } \\
\cline { 2 - 5 } & $\begin{array}{c}\text { One } \\
(\mathbf{n = 1 3 4 )}\end{array}$ & $\begin{array}{c}\text { Two } \\
(\mathbf{n = 1 4 )}\end{array}$ & $\begin{array}{c}\text { Three } \\
\text { (n=2) }\end{array}$ & \\
\hline Spontaneous & $\mathbf{2 9}$ & $\mathbf{1}$ & $\mathbf{0}$ & $30(20.00 \%)$ \\
\hline $\begin{array}{c}\text { Spontaneous + } \\
\text { Augmented }\end{array}$ & $\mathbf{1 3}$ & $\mathbf{0}$ & $\mathbf{0}$ & $13(8.67 \%)$ \\
\hline Induction & $\mathbf{5 8}$ & $\mathbf{0}$ & $\mathbf{0}$ & $58(68.67 \%)$ \\
\hline Elective C/S & $\mathbf{2 9}$ & $\mathbf{1 3}$ & $\mathbf{2}$ & $44(29.33 \%)$ \\
\hline Direct emergency & $\mathbf{5}$ & $\mathbf{0}$ & $\mathbf{0}$ & $5(3.33 \%)$ \\
\hline
\end{tabular}

Table 4: Type of Labour in Present Pregnancy in Relation

to Number of Previous Caesarean Section

\begin{tabular}{|c|c|c|c|c|c|c|}
\hline Type of labour & Total & $\begin{array}{l}\text { Vaginal } \\
\text { delivery }\end{array}$ & $\%$ age & $\begin{array}{c}\text { Failed } \\
\text { trial }\end{array}$ & $\begin{array}{l}\text { Caesarean } \\
\text { section }\end{array}$ & $\%$ \\
\hline \multicolumn{7}{|c|}{ (A) Previous One Caesarean Section } \\
\hline Spontaneous & 29 & 20 & $68.97 \%$ & 9 & 9 & $31.03 \%$ \\
\hline $\begin{array}{c}\text { Spontaneous + } \\
\text { Augmented }\end{array}$ & 13 & 11 & $84.62 \%$ & 2 & 2 & $15.38 \%$ \\
\hline Induced & 58 & 29 & $50.00 \%$ & 29 & 29 & $50.00 \%$ \\
\hline $\begin{array}{c}\text { Elective caesarean } \\
\text { Section }\end{array}$ & 29 & 0 & $0.00 \%$ & 0 & 29 & $100.00 \%$ \\
\hline $\begin{array}{c}\text { Emergency } \\
\text { admission }\end{array}$ & 5 & 0 & $0.00 \%$ & 0 & 5 & $100.00 \%$ \\
\hline & 134 & 60 & & 41 & 74 & \\
\hline \multicolumn{7}{|c|}{ (B) Previous Two Caesarean Section } \\
\hline Spontaneous & 1 & 0 & $0.00 \%$ & 1 & 1 & $7.14 \%$ \\
\hline $\begin{array}{c}\text { Elective Caesarean } \\
\text { Section }\end{array}$ & 13 & 0 & $0.00 \%$ & 0 & 13 & $92.86 \%$ \\
\hline & 14 & $\mathbf{0}$ & $0.00 \%$ & 1 & 14 & \\
\hline \multicolumn{7}{|c|}{ (C) Previous Three Caesarean Section } \\
\hline $\begin{array}{l}\text { Elective Caesarean } \\
\text { Section }\end{array}$ & 2 & 0 & $0.00 \%$ & 0 & 2 & $100.00 \%$ \\
\hline
\end{tabular}

\begin{tabular}{|c|c|c|c|c|c|c|c|}
\hline Type of labour & Total & ST & TS & NPOL & FD & SD & OTHERS \\
\hline \multicolumn{7}{|c|}{ (A) Previous One Caesarean Section } \\
\hline Spontaneous & $9 / 29$ & 4 & 1 & 0 & 2 & 2 & 0 \\
\hline Induced & $29 / 58$ & 10 & 0 & 6 & 13 & 0 & 0 \\
\hline $\begin{array}{c}\text { Spontaneous + } \\
\text { Augmented }\end{array}$ & $2 / 13$ & 1 & 0 & 1 & 0 & 0 & 0 \\
\hline
\end{tabular}




\section{ORIGINAL ARTICLE}

\begin{tabular}{|c|c|c|c|c|c|c|c|}
\hline $\begin{array}{c}\text { Elective caesarean } \\
\text { Section }\end{array}$ & $29 / 29$ & 1 & 26 & 0 & 0 & 0 & 2 \\
\hline Direct Emergency & $5 / 5$ & 1 & 0 & 0 & 3 & 0 & 1 \\
\hline Total & $74 / 134$ & $\begin{array}{c}17 \\
(12.69 \%)\end{array}$ & $\begin{array}{c}27 \\
(20.15 \%)\end{array}$ & $\begin{array}{c}7 \\
(5.22 \%)\end{array}$ & $\begin{array}{c}18 \\
(13.43 \%)\end{array}$ & $\begin{array}{c}2 \\
(1.49 \%)\end{array}$ & $\begin{array}{c}3 \\
(2.24 \%)\end{array}$ \\
\hline \multicolumn{8}{|c|}{ (B) Previous Two Caesarean Section } \\
\hline Spontaneous & $1 / 1$ & 1 & 0 & 0 & 0 & 0 & 0 \\
\hline $\begin{array}{c}\text { Elective Caesarean } \\
\text { Section }\end{array}$ & $13 / 13$ & 0 & 12 & 0 & 0 & 0 & 1 \\
\hline Total & $14 / 14$ & $\begin{array}{c}1 \\
(7.14 \%)\end{array}$ & $\begin{array}{c}12 \\
(85.71 \%)\end{array}$ & $\mathbf{0}$ & $\mathbf{0}$ & 0 & $\begin{array}{c}1 \\
(7.14 \%)\end{array}$ \\
\hline \multicolumn{8}{|c|}{ (C) Previous Three Caesarean Section } \\
\hline \multirow[t]{2}{*}{$\begin{array}{c}\text { Elective Caesarean } \\
\text { Section }\end{array}$} & $2 / 2$ & 0 & 2 & 0 & 0 & 0 & 0 \\
\hline & $2 / 2$ & 0 & $2(100 \%)$ & 0 & 0 & 0 & 0 \\
\hline & & $\begin{array}{l}\text { Adication } \\
\text { ype of La }\end{array}$ & $\begin{array}{l}\text { f Ceaserea } \\
\text { our in Pres }\end{array}$ & ection & $\begin{array}{l}\text { ording } \\
y\end{array}$ & & \\
\hline
\end{tabular}

\begin{tabular}{|c|c|c|c|c|c|}
\hline \multirow{2}{*}{$\begin{array}{c}\text { Indication Previous } \\
\text { Caesarean Section }\end{array}$} & Total & \multicolumn{4}{|c|}{ Mode of Delivery } \\
\cline { 2 - 6 } & & $\begin{array}{c}\text { Caesarean } \\
\text { Section }\end{array}$ & Percentage & Vaginal & Percentage \\
\hline Fetal distress & $\mathbf{6 9}$ & 34 & $49.28 \%$ & 35 & $50.72 \%$ \\
\hline Non progress of labour (NPOL) & $\mathbf{5 3}$ & 43 & $81.13 \%$ & 10 & $18.87 \%$ \\
\hline Breech & $\mathbf{8}$ & 2 & $25.00 \%$ & 6 & $75 \%$ \\
\hline $\begin{array}{c}\text { Pregnancy induced } \\
\text { hypertension (PIH) }\end{array}$ & $\mathbf{1 6}$ & $\mathbf{9}$ & $\mathbf{5 6 . 2 5 \%}$ & 7 & $43.75 \%$ \\
\hline Others & $\mathbf{4}$ & $\mathbf{3}$ & $\mathbf{7 5 . 0 0 \%}$ & 1 & $25 \%$ \\
\hline p value & \multicolumn{5}{|c|}{$<0.01$} \\
\hline \\
Previous Caesarean Section with the Present Mode of Delivery \\
\hline
\end{tabular}

\begin{tabular}{|c|c|c|c|c|c|}
\hline \multirow{2}{*}{ Maternal age (Years) } & Total & \multicolumn{4}{|c|}{ Mode of Delivery } \\
\cline { 2 - 6 } & & Caesarean Section & Percentage & Vaginal & Percentage \\
\hline $21-25$ & 20 & 9 & $45.00 \%$ & 11 & $55.00 \%$ \\
\hline $26-30$ & 78 & 47 & $60.26 \%$ & 31 & $39.74 \%$ \\
\hline $31-35$ & 48 & 32 & $66.67 \%$ & 16 & $33.33 \%$ \\
\hline $36-40$ & 4 & 3 & $75.00 \%$ & 1 & $25.00 \%$ \\
\hline$p$ value & \multicolumn{4}{c}{$<0.01$} \\
\hline \\
Table 8: Relationship between the Maternal \\
Ages with the Present Mode of Delivery
\end{tabular}




\section{ORIGINAL ARTICLE}

\begin{tabular}{|c|c|c|c|c|c|}
\hline \multirow{2}{*}{ Baby Birth Weight (kg) } & Total & \multicolumn{4}{|c|}{ Mode of Delivery } \\
\cline { 2 - 6 } & & Caesarean Section & Percentage & Vaginal & Percentage \\
\hline$<2.5$ & 13 & 10 & $76.92 \%$ & 3 & $23.08 \%$ \\
\hline $2.5-3.0$ & 95 & 59 & $62.11 \%$ & 36 & $37.89 \%$ \\
\hline $3.0-3.5$ & 38 & 30 & $78.95 \%$ & 8 & $21.05 \%$ \\
\hline $3.5-4.0$ & 4 & 4 & $100.00 \%$ & 0 & $0.00 \%$ \\
\hline p value & \multicolumn{4}{c}{$<0.10$} \\
\hline \multicolumn{6}{|c|}{$\begin{array}{r}\text { Table 9: Relationship between the Baby Weights } \\
\text { with the Present Mode of Delivery }\end{array}$} \\
\hline
\end{tabular}

\section{REFERENCES:}

1. Hashima JN. Eden KB. Ostcnveil P, Nygren P, Guise JM. Predicting vaginal birth after cesarean delivery: A review of prognostic factors and screening tools. AM.; Obstet Gynceol. 2004; 190:54755.

2. Mastrobattista JM. Vaginal birth after cesarean delivery. Obstet Gynecol Clinic North Am. 1999; 26: 295-304.

3. Jhaveri A. Obstetric career after previous caesarean section. J Obstet Gyncol India. 1969; 19:561.

4. Landon MB, Hauth JC, Leveno KJ, Spong CY, Leindecker S, Varner MW, et al. Maternal \& Perinatal outcomes associated with a trial of labour after prior caesarean delivery. N Engl J Med. 2004; 351:2581-9.

5. Sakala EP, Kaye 5, Murray RD, Munson LI. Oxytocin use after previous cesarean: Why a higher rate of failed labour trial? Obstet 1990; 73: 356-58.

6. Troyes IR, Parisi ViA. Obstetric parameters affecting success in a trial of labour: Designation of a scoring system. Am J Obstet Gynecol 1992; 167: 1099-104.

7. Vardhan S, Behera RC, Sandhu GS, Singh A, Bandhu HC. Vaginal birth after caesarean delivery. J Obstet Gynecol India 2006; 56(4): 320-3.

8. Tan PC, Subramaniam RN, Omar SZ. Lab our and perinatal outcome in women at term with one previous lower segment caesarean: A review of 1000 consecutive cases. Aust NZJ Obstet Gynecol 2007; 47(1):31-6.

9. Shah JM, Mehta MN, Gokhale AV. Vaginal birth after caesarean delivery. Obs \& Gynae Today 2007; 12(6):280-1.

10. Dhall K, Mittal SC, Grover V. Child birth following primary caesarean section: Evaluation of a scoring system. Int J Gynecol Obstet 1987; 25:199-201.

11. Chhabra S, Arora G. Delivery in women with one previous caesarean section. J Obstet Gynecol India 2006; 56(4):304-7.

12. Bhatt BPR, Savant R, Kamath A. Outcome of a Post Caesarean Pregnancy in a Tertiary Centre of a developing country. Journal of Clinical and Diagnostic Research 2010 February; 3:2005-9.

13. Suman Poddar. "A Study of the Outcome of Subsequent Pregnancy following Previous Cesarean Section". Journal of Evolution of Medical and Dental Sciences 2014; Vol. 3, Issue 06, February 10; Page: 1466-1473, DOI: 10.14260/jemds/2014/2009. 


\section{ORIGINAL ARTICLE}

14. Zelop CM, Shipp TD, Repke JT, Cohen A, Lieberman E. Outcomes of trial of labour following previous cesarean delivery among women with fetuses weighing $>40002 \mathrm{~m}$. Am J Obstet Gynecol 2001; 185: 903-5.

\section{AUTHORS:}

1. Gurpreet Kaur Nandmer

2. Anjali Kanhere

\section{PARTICULARS OF CONTRIBUTORS:}

1. Assistant Professor, Department of Obstetrics and Gynaecology, PCMS \& RC, Bhopal, Madhya Pradesh.

2. Professor, Department of Obstetrics and Gynaecology, PCMS \& RC, Bhopal, Madhya Pradesh.

FINANCIAL OR OTHER COMPETING INTERESTS: None

\section{NAME ADDRESS EMAIL ID OF THE} CORRESPONDING AUTHOR:

Anjali Kanhere,

Professor,

Department of Obstetrics and Gynaecology,

PCMS \& RC, Bhopal-462044,

Madhya Pradesh, India.

E-mail: kanhereanju@yahoo.com

Date of Submission: 25/08/2015.

Date of Peer Review: 26/08/2015.

Date of Acceptance: 07/09/2015.

Date of Publishing: 14/09/2015. 